NASA Technical Memorandum 87254

\title{
Analysis of Fully Stalled Compressor
}

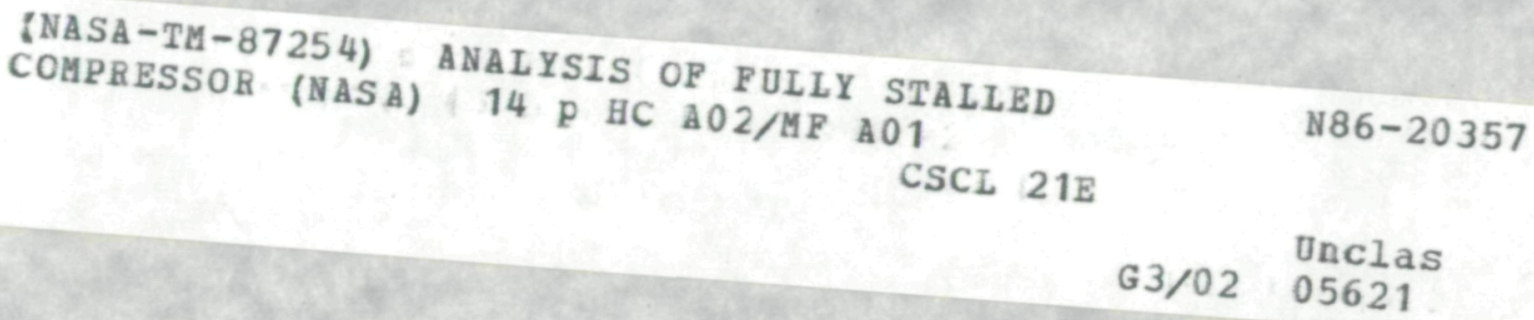

Wojciech Rostafinski

Lewis Research Center

Cleveland, Ohio

Prepared for the

4th Joint Fluid Mechanics, Plasma Dynamics and Laser Conference cosponsored by the American Institute of Aeronautics and Astronautics and the American Society of Mechanical Engineers

Atlanta, Georgia, May 12-14, 1986

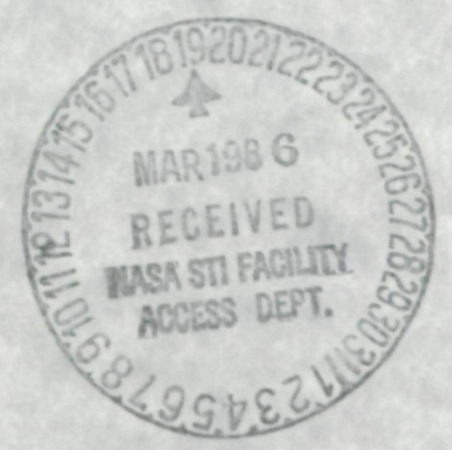




\title{
ANALYSIS OF FULLY STALLED COMPRESSOR
}

\author{
Wojcrech Rostafinsk 1 \\ National Aeronautics and Space Administration \\ Lew1s Research Center \\ Cleveland, Ohro 44135
}

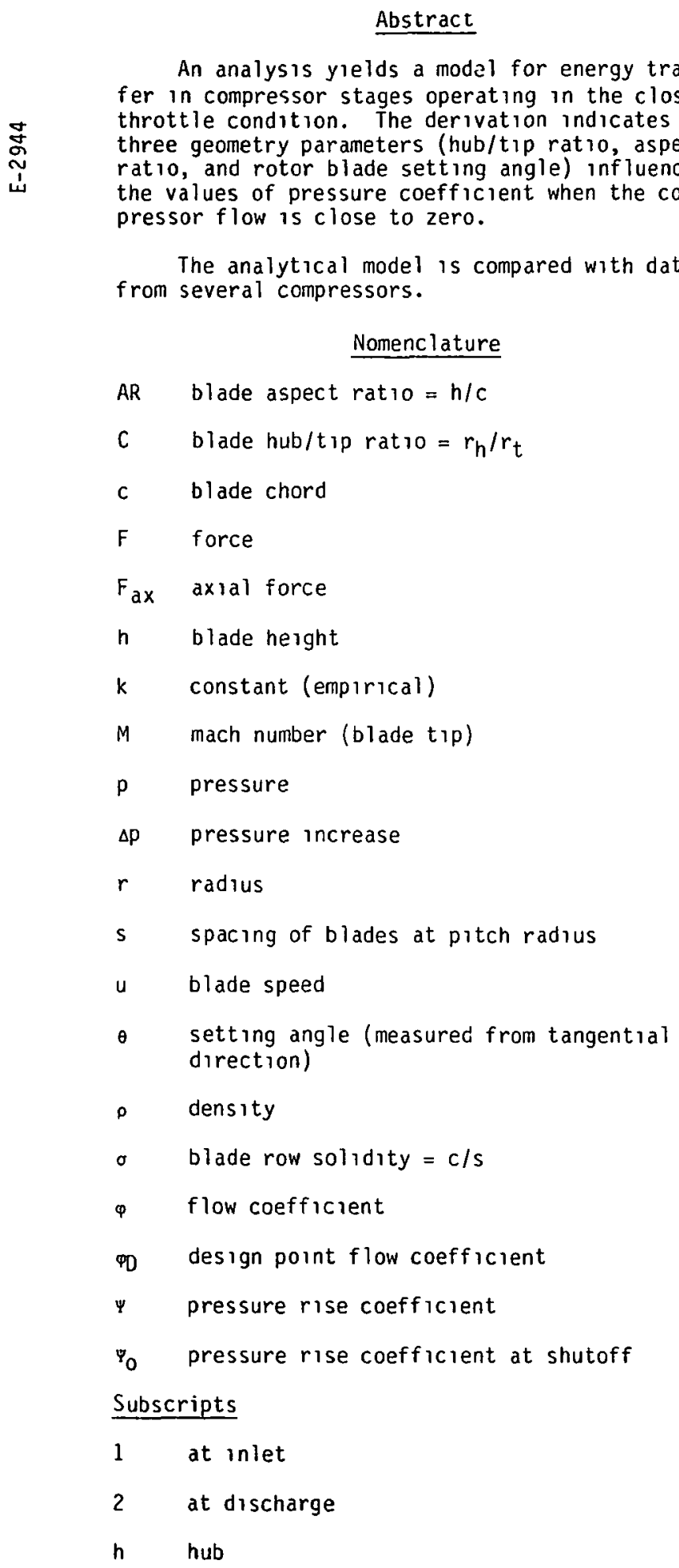
m mean
$t \quad t i p$

\section{Summary}

The present study examines the stalled operation of 27 single-stage and multistage compressor configurations. This examination reveals an absence of any obvious dependence of closedthrottle pressure coefficient on any of the design parameters.

An approximation of paddle-wheel operation is then used to suggest a zero-throughflow model which, when combined with an empirical correction factor, would predict the pressure coefficient of compressors at shutoff. The derivation indicates that three compressor-rotor design parameters (hub/tip ratio, aspect ratio, and setting angle) influence the values of pressure coefficient when compressor flow is close to zero.

The analytical modeling so far derived needs further development. The model yields a general trend of the variation of pressure coefficient with the compressor design parameters, but the comparison with experimental data shows considerable scatter, leaving room for improvement. It is hoped that this study will encourage others to pursue more in-depth examinations of stalled compressor operation.

\section{Introduction}

Unt 1 l a few years ago, knowledge of compressor performance in highly throttled regimes was very limited. Recently, however, the rotating stall, and more particularly, the pressure rise in a compressor stage and in multistage compressors operating with closed throttle have been studied and reported extensively in Ref. 1. The authors conclude that total-to-static pressure rise per stage of a closed-throttle compressor is largely independent of the compressor design. In other words, at closed throttle all axial flow compressors tend to achieve the same average pressure rise per stage. This average pressure coeff $1-$ clent, based on blade velocity at the blade pitch line, was 0.11 for 13 different low-speed compressors having hub/tip ratios of 0.8 . The deviations from this mean were not small, ranging from +27 percent to -36 percent of this value. The published design characteristics (design flow coefficient, camber, blade setting angle, and degree of reaction) of the 13 compressors were insufficient to permit an assessment of the significance of these deviations, therefore, only statistical trends could be established.

The author concluded that an important contribution to improved compressor design would be clarification of the fluid dynamics associated 
with the closed throttle condition and derivation of a model to explain the nearly constant values of the stall pressure rise coefficient per stage for axial-flow compressors.

In a discussion included in Ref. 1, a graphical presentation was given of the operating characteristics of 22 additional low-speed compressors with flow rates that ranged from those exceeding the design-point value down to those in the deep stall region. Unfortunately, design data did not accompany the performance information, and it was not clear whether there was any consistent relationship between the design parameters and the closed-throttle pressure coefficients, which varled from about 0.05 to 0.18 . The average pressure coefficient per stage at closed throttle was 0.118 , with deviations ranging from -50 percent to +90 percent. We note that again, in this case, the average pressure coefficient approaches the previously established value of 0.11 .

Because the pressure after the initial dropoff in stall remains relatively constant once a full-span stall is established, one might think of approximating the pressure coefficient per stage at closed-throttle condition using methods outlined in Refs. 2 and 3. In Ref. 2, a correlation is given between the pressure drop at stall and the maximum compressor pressure ratio just prior' to stall. It is interesting to note that this correlation, shown in Fig. 1 , applies to both singlestage and multistage compressors. In a recent publication, 3 the author presented a semi-empirical correlation relating the static pressure rise of a compressor stage operating at staill to a cascade passage geometry. This correlation can be used with an off-design code to obtain a useful estimate of compressor stalling pressure capability.

Herein, we are examining the stalled opera$t$ ion of 27 single-stage and multistage compressors configurations. Two of the configurations operate with high flow Mach numbers, typical of advanced stages. An approximation of paddle-wheel operation is used to suggest a zero-throughflow model which, when combined with an empirical correction factor, would predict the pressure coefficient of compressors at shutoff. The analytical results are compared with the closed-throttle pressure coefficients for the 27 compressors.

\section{Experimental Data}

Design data and available information on the performance of 27 single-stage and multistages compressors $4-10$ tested in deep stall and with very low flow coefficients are summarized in Table 1. The hub-tip ratios of the 25 low-speed compressors ranged from 0.6 to 0.88 , the solidities from 0.606 to 1.37 , and the blades aspect ratios from 0.8 to 4.6 . The pitch-1ine speeds varied from a very low value of $36 \mathrm{~m} / \mathrm{sec}(118 \mathrm{ft} / \mathrm{sec})$ to $85 \mathrm{~m} / \mathrm{sec}(279 \mathrm{ft} / \mathrm{sec}$ ), while the experimental pressure coefficients per stage at closed-throttle condition varied from 0.066 to 0.226 . The hub tip ratios of the two supersonic compressors were low: 0.527 and 0.64 . The solidities were 1.77 and 1.35 , respectively, the aspect ratios 3.1 and 1.0 . The pitch line speeds were 288 and $325 \mathrm{~m} / \mathrm{sec}$ (943 and $1064 \mathrm{ft} / \mathrm{sec})$, while the tip speeds were $350 \mathrm{~m} / \mathrm{sec}$ and $425 \mathrm{~m} / \mathrm{sec}(1150 \mathrm{ft} / \mathrm{sec}$ and $1394 \mathrm{ft} / \mathrm{sec})$, corresponding to Mach numbers 1.267 and 1.045 , respectively.

Some of the experimental performance data of low-speed and high-speed compressors are limited to flows somewhat greater than zero. Consequently, those performance characteristics had to be extrapolated down to flow coefficients of zero. Figure 2 shows one of the low-speed compressor performance maps extending all the way to zero flow; Figs. 3 and 4 show the performance maps of the two high speed compressors. The extrapolations to zero flow, which were needed, carry some nominal margin of error. Even with discrepancies reaching several percentage points, they would not alter the conclusions of this study.

An examination of the design and performance data for all 27 compressor bullds will be made before attempting to model the operation of compressor stages at complete shutoff. It must be stressed at this time, that very few of experimental performance data were obtained by design. They were rather a by-product of compressor stability studies.

Several design parameters for these compressors have been plotted as a function of the pressure rise coefficient in Fig. 5. The results reveal the absence of any well-behaved dependence of the closed-throttle pressure coefficient on the design parameters. In other words, regular variations in the data are not apparent, and no single parameter shown accounts consistently for the change in pressure coefficient at zero-capacity condition.

Examination of the performance maps for compressors run at several speeds (Figs. 3 and 4 ) reveals two interesting characteristics of the part speed operation of compressors at shutoff.

First of all, there is a reversal of speed lines on a map plotted in terms of the pressure coefficient. In the region from stall to shutoff, the lowest speed line on a pressure coefficient map is on the top of the map, while the design speed line is on the bottom. In other words, as the rotational speed decreases, the pressure coefficient increases when the operating points are to the left of the stall line and particularly when the shutoff condition is reached. It should be also noticed that, on the map in terms of the pressure coefficients, the stall line is quite flat.

The second characteristic associated with operation of compressor stages at the closed throttle condition is an obviously reduced dependence of the pressure coefficient on speed. The effects of compressibility are small in the case of the low-speed compressors, but are more pronounced with increasing compressor blade tip Mach number.

\section{Development of a Flow Model}

Little is understood about the operation of compressors in deep stall, but it is generally accepted that at the closed-throttle condition, and even at very low flow coefficients, one stall region covers the entire blade row of a compressor 
stage. Because of this, stall zones extend from hub to tip of the blades, and blockage of the throughflow area is nearly complete.

It will be, therefore, assumed that the fluid trapped within the stalled zone will be impacted by the moving compressor blades. In this situation, the compressor behavior will be analogous to the churning action of the revolving plates of a paddle wheel. The idea of a paddle wheel was also advanced in Ref. 11. A simple two-dimensional formulation of energy transfer in such a type of flow may be based, most conveniently, on the principle of the change of momentum. In other words, the axial component of force exerted by blades on the fluid will be equal to the total change of fluid momentum in that direction.

Consider a "jet" of air impinging on a blade as shown on Fig. 6. The component of the inlet momentum perpendicular to the blade equals: p. area. $u^{2} \cdot \sin ^{2} \theta$ where "area" indicates the "jet" cross section, $u$ is the jet speed which in this case is the blade tangential pitch line or average velocity, and $\theta$ is the blade setting angle (measured to the tangential direction).

The component of the leaving momentum perpendicular to the blade is identically zero because the leaving flow is tangent to the blade. As force equals inlet momentum minus leaving momentym, the force normal to the blade is $F=p \cdot a r e a . u^{2} \cdot \sin ^{2} \theta$ and its axial component is

$$
F_{a x}=\rho \cdot \operatorname{area} \cdot u^{2} \cdot \sin ^{2} \theta \cos \theta
$$

Before going any further, let us assume that the "area" under consideration equals the blade area, hc, height times chord, and the velocity $u$ is an average over the blade. Then

$$
u^{2}=\frac{1}{2}\left(u_{t}^{2}+u_{h}^{2}\right)=\frac{1}{2} u_{t}^{2}\left(1+c^{2}\right)
$$

where $C=r_{h} / r_{t}$. Substituting,

$$
F_{a x}=\frac{1}{2} \rho(h c) u_{t}^{2}\left(1+c^{2}\right) \sin ^{2} \theta \cos \theta
$$

It is not known how uniformly this force is distributed over the blades and oyer the compressor cross-sectional annular area $\pi\left(r \frac{2}{-} r_{h}\right)$. It may be assumed for the time being that $F_{\text {ax }}$ acts on the entire area and that it reflects a pressure difference across the compressor blade row.

$$
\Delta p=\frac{\text { force }}{\text { area }}=\frac{F_{a x}}{\pi\left(r_{t}^{2}-r_{h}^{2}\right)}
$$

or

$$
\Delta p=\frac{1}{2} \frac{\rho(h c)}{\pi\left(r^{2} t-r^{2}\right)} u_{t}^{2}\left(1+c^{2}\right) \sin ^{2} \theta \cos \theta
$$

Now

$$
\frac{h c}{\left(r_{t}^{2}-r_{h}^{2}\right)}=\frac{(1-c)^{2}}{\operatorname{AR}\left(1-c^{2}\right)}
$$

so that

$$
\Delta p=\left[\frac{k}{(2 \pi A R)}\right]\left(\rho u_{t}^{2}\right)\left(1+c^{2}\right) \frac{(1-C)^{2}}{\left(1-c^{2}\right)} \sin ^{2} \theta \cos \theta
$$

and since

$$
\begin{aligned}
u_{m}=\frac{1}{2}(1+c) u_{t} & =\frac{\Delta p}{\left(\rho u_{m}^{2}\right)} \\
& =\frac{2 k}{[\pi A R]}\left(1+c^{2}\right) \frac{(1-c)^{2}}{(1+c)^{2}\left(1-c^{2}\right)} \sin ^{2} \theta \cos \theta
\end{aligned}
$$

where $k$ is a constant intended to compensate for the distribution of forces on the two unknown effective areas taken into consideration. Its value $(k=15.75)$ was determined by matching only one data point of the 27 known experimental values of $\Psi_{O}$. The data point was determined on the basis of best agreement for all 27 compressors. Using this value of $k$, the calculated closedthrottle pressure coefficients are shown in Tables 2 and 3.

Modeling of the two transonic compressors required that on top of the derived momentum exchange process, a correction be introduced to account for the existence of shocks in the blade passages. Using the thus far obtained relation for $\Psi_{O}$, the uncorrected values for the pressure coefficient are given in the third column of Table 3. These values are much higher than the experimental data. We may thus postulate that shocks prevent the rotating blades from producing the calculated pressure rise. In view of this, we propose to use a correction factor $\sqrt{M^{2}-1}$ where the Mach number $M$ is based on blade tip velocity. As indicated in Ref. 12, pressure differences on areas subject to supersonic flows depend on the parameter $\sqrt{M^{2}-1}$. The fourth column of Table 3 gives the new corrected values of $\Psi_{0}$ for the transonic compressors.

The calculated values of closed-throttle pressure coefficient are plotted agarnst the experimental values in Fig. 7. The vertical distance between a point and the $45^{\circ}$ line represents the deviation between calculated and experimental values. As seen from the dashed lines, which represent +25 percent deviation, most of the calculated vaTues are within 25 percent of the experimental values. While there is a significant amount of scatter in the correlation, the mode does produce a trend of increasing calculated values with increasing experimental values. Thus, the model reflects the influence of compressorrotor hub/tip ratio, aspect ratio, and setting angle on the closed-throttle pressure coefficient.

Caution must be exercised in the use of this correlation, especially for transonic compressors because the Mach number correction was based on only two avallabie data points. It must be recognized that this correlation is a preliminary one and will require adjustments in the future. However, it is belleved that this correlation represents an improvement over the previous assumption that closed-throttle pressure coefficient was a constant independent of compressor geometry. 
The established relationship was based on data for single stages and stage averages for multistage compressors. As stated before, the calculated $\Psi_{0}$ pertain to the normalized pressure rise per stage. In multistage compressors of $n$ stages, the overall compressor $\Psi_{0} w_{111}$ be $n$ times the stage (average stage) value. Values of the stage pressure coefficient are simply additive because their evaluation was based on axial forces which are additive. In some situations when multistage compressors are considered, the first and the last stage may have quite different $\Psi_{0}$ than the average because of the effect of inlet and outlet plenum volumes.

The analytical model thus far obtained does not account for compressor speed because the adopted incompressible fluid flow model cannot yield any dependence of the pressure coefficient on rotational speed. The experimental data do indicate, however, that such a dependence exists. With the low speed compressors, the compressibility effects are small; with the transonic compressors, they are quite pronounced.

The limited avallable data on part speed operation of compressors at zero flow yleld the following information: in the case of the low speed compressors (part speed data are avallable on compressors 5 and 6 ), the $\Psi_{0}$ varies inversely with compressor speed to the power of 0.25 . With the transonic compressors (compressors 26 and 27), the speed ratio exponent averages 0.8 (see Fig. 8).

\section{Concluding Remarks}

Using a momentum exchange model, an analytical expression for compressor stage pressure coeff 1cient has been obtained for the closed-throttle condition. In this equation, an empirical constant was determined using design and performance data from one low speed compressor. The derived expression for pressure coefficient was then evaluated using data from several low-speed and two transonic compressors.

The derived correlation reveals that for lowspeed single-stage and multistage compressors as well as for transonic compressors, the pressure rise coefficient per stage at closed-throttled condition is not a constant, and its value is influenced by the hub/tip ratio, blade aspect ratio, and the setting angle of the rotor blades. For the transonic compressors compressibility effects must also be considered. In part speed operations, the closed-throttle pressure coefficients are inversely proportional to a power of the rotational speed.

The proposed expressions shed light on the fluid mechanics processes responsible for genera$t$ ion of pressure in a compressor operating with closed throttle. The analytical modeling so far derived needs further developement. The adopted model yields a general trend of the variation of the pressure coefficient with compressor design parameters. Most of the calculated values of closed-throttle pressure coefficient are within 25 percent of the experimental data. While there is scatter in the correlation, it does represent a marked improvement over the previous assumption that closed-throttle pressure coefficient is a constant independent of compressor geometry.

Possible improvements to the correlation may include the effect of stator geometry and perhaps that of the inlet guide vanes. Most useful in this respect would be tests run with the explicit intention to evaluate the effect of compressor geometry on closed-throttle compressor operation. ' Thus far no such tests were ever run. It is hoped that the results of this study will encourage others to pursue in-depth analytical and experimental examinations of stalled compressor operation.

\section{References}

1. Day, I.J., Greitzer, E.M., and Cumpsty, N.A., "Prediction of Compressor Performance in Rotating Stall," Journal of Englneering for Power, Vol. 100, No. 1, Jan. 1978, pp. 1-14.

2. Johnson, I.A. and Bullock, R.0., eds., Aerodynamic Design of Axial-Flow Compressors, NASA $\mathrm{SP}-\overline{36}, 1965$.

3. Koch, C.C., "Stalling Pressure Rise Capability of Axial Flow Compressor Stages," Journal of Engineering for Power, Vol. 103, No. 4, oct. 1981, pp. 645-656.

4. Iura, T. and Rannie, W.D., Observations of "Propagatıng Stall in Axial-Flow Compressors," Report No. 4, Mechanical Engineering Lab, California Institute of Technology, Apr. 1953.

5. Greitzer, E.M., "Surge and Rotating Stall in Axial Flow Compressors: Part II Experimental Results and Comparison With Theory," Journal of Engrneering for Power, Vol. 98, No. 2 , Apr. 1976, pp. 199-217.

6. Gamache, R.N., "Axial Compressor Reversed Flow Performance," PhD Dissertation, Massachusetts Institute of Technology, 1985.

7. Day, I.J., "Axıal Compressor Stal1," PhD Dissertation, Christ's College, Cambridge University, 1976.

8. Wisler, D.C., General Electric Company, Evendale, Ohio, private communication.

9. Urasek, D.C., Steınke, R.J., and Cunnan, W.S., "Stalled and Stall-Free Performance of AxialFlow Compressor Stage With Three Inlet-GuideVane and Stator-Blade Settings," NASA TN D-8457, 1977.

10. Mason, J.R., "Post-Stall Compressor Model," Pratt and Whitney Aircraft, West Palm Beach, FL, P7WA/GPD/FR-16286, Jan. 1983. (NASA CR-168048.)

11. Day, I.J. and Cumpsty, N.A., "The measurement and Interpretation of Flow Within Rotating Stall Cells in Axial Compressors," Journal of Mechanical Engineering Science, Vol. 20, No. 2, Apr. 1978, pp. 101-115.

12. Shapiro, A.H., The Dynamics and Thermodynamics of Compressible Fluid F.low, The Roland Press Company, NY, 1953. 
TABLE 1. - DESIGN AND PERFORMANCE DATA ON 27 COMPRESSOR 8UILDS

\begin{tabular}{|c|c|c|c|c|c|c|c|c|c|}
\hline \multirow{3}{*}{$\begin{array}{l}\text { Designation } \\
\text { number }\end{array}$} & \multirow[t]{3}{*}{ Reference } & \multicolumn{8}{|c|}{ Compressor } \\
\hline & & \multicolumn{5}{|c|}{ Design } & \multicolumn{3}{|c|}{ Performance } \\
\hline & & $\begin{array}{c}\text { Hub/tip } \\
\text { ratio, } \\
\text { C }\end{array}$ & $\underset{\sigma}{\text { Solidity, }}$ & $\begin{array}{c}\text { Aspect } \\
\text { ratio, } \\
\text { AR }\end{array}$ & $\begin{array}{c}\text { Stagger } \\
\text { angle, } \\
6\end{array}$ & $\begin{array}{c}\text { Number } \\
\text { of } \\
\text { stages, } \\
n\end{array}$ & $\begin{array}{c}\text { Mean } \\
\text { blade } \\
\text { speed, } \\
u_{m}\end{array}$ & $\begin{array}{c}\text { Design } \\
\text { f low } \\
\text { parameter, } \\
9 D \\
\end{array}$ & $\begin{array}{c}\text { Experimental } \\
\text { pressure } \\
\text { coefficient, } \\
\square_{0} \\
\end{array}$ \\
\hline $\begin{array}{l}1 \\
2 \\
3 \\
4 \\
5 \\
6\end{array}$ & $\begin{array}{l}4 \\
4 \\
4 \\
5 \\
6 \\
6\end{array}$ & $\begin{array}{l}0.6 \\
.6 \\
.6 \\
.7 \\
.88 \\
.88\end{array}$ & $\begin{array}{r}0.995 \\
.862 \\
.862 \\
1.24 \\
1.373 \\
1.373\end{array}$ & $\begin{array}{l}2.7 \\
2.7 \\
2.7 \\
2.0 \\
.8 \\
.8\end{array}$ & $\begin{array}{l}50.0 \\
45.5 \\
45.5 \\
63.7 \\
51.4 \\
46.4\end{array}$ & $\begin{array}{l}1 \\
1 \\
3 \\
1\end{array}$ & $\begin{array}{l}118 \\
118 \\
118 \\
279 \\
236 \\
236\end{array}$ & $\begin{array}{l}0.45 \\
.45 \\
.45 \\
.55 \\
.6 \\
.6\end{array}$ & $\begin{array}{r}0.226 \\
.214 \\
.195 \\
.158 \\
.128 \\
.145\end{array}$ \\
\hline $\begin{array}{r}7 \\
8 \\
9 \\
10 \\
11 \\
12 \\
13 \\
14 \\
15 \\
16 \\
17 \\
18 \\
19\end{array}$ & ? & 0.8 & $i_{i=13}^{1.06}+1.06$ & 2 & $\left.\right|_{70} ^{40}+40$ & $\begin{array}{l}1 \\
3 \\
1 \\
2 \\
3 \\
4 \\
1 \\
2 \\
3 \\
1 \\
2 \\
3 \\
4\end{array}$ & $\stackrel{165}{1}$ & $\begin{array}{l}0.35 \\
.35 \\
.55 \\
.71 \\
.71 \\
.71 \\
1.0\end{array}$ & $\begin{array}{r}0.137 \\
.135 \\
.100 \\
.105 \\
.103 \\
.104 \\
.075 \\
.125 \\
.117 \\
.066 \\
.100 \\
.106 \\
.110\end{array}$ \\
\hline $\begin{array}{l}20 \\
21 \\
22 \\
23 \\
24 \\
25\end{array}$ & 8 & $\begin{array}{l}0.7 \\
.85 \\
i^{7}\end{array}$ & $\begin{array}{l}0.97 \\
1.11 \\
1.07 \\
.606 \\
1.08 \\
1.47\end{array}$ & $\begin{array}{l}1.83 \\
1.25 \\
2.0 \\
4.6 \\
4.6 \\
2.8\end{array}$ & $\begin{array}{l}48 \\
47.8 \\
57 \\
57 \\
50 \\
57\end{array}$ & $1^{4}$ & $\begin{array}{l}144 \\
171 \\
144\end{array}$ & (a) & $\begin{array}{r}0.167 \\
.131 \\
.156 \\
.125 \\
.111 \\
.111\end{array}$ \\
\hline $\begin{array}{l}26 \\
27\end{array}$ & $\begin{array}{r}9 \\
10\end{array}$ & $\begin{array}{r}0.53 \\
.63\end{array}$ & $\begin{array}{l}1.77 \\
1.35\end{array}$ & $\begin{array}{l}3.1 \\
1.0\end{array}$ & $\begin{array}{l}39 \\
41.2\end{array}$ & $\begin{array}{l}1 \\
3\end{array}$ & $\begin{array}{r}1064 \\
937\end{array}$ & $\begin{array}{c}0.46 \\
.5\end{array}$ & $\begin{array}{c}0.145 \\
.10\end{array}$ \\
\hline
\end{tabular}

a Not avarlable.

TABLE 2. - COMPARISON OF CALCULATED AND EXPERIMENTAL VALUES OF THE PRESSURE COEFFICIENT AT ZERO FLOW FOR 25 LOW-SPEED COMPRESSORS

\begin{tabular}{|c|c|c|c|c|c|}
\hline \multicolumn{6}{|c|}{ Pressure coefficient at shutoff, $\Psi_{0}$} \\
\hline Measured & \multicolumn{2}{|c|}{ Calculated } & \multirow{2}{*}{$\begin{array}{c}\text { Measured } \\
\text { Experimental } \\
\text { pressure } \\
\text { coefficient, } \\
\Psi_{0}\end{array}$} & \multicolumn{2}{|c|}{ Calculated } \\
\hline $\begin{array}{c}\text { Experimental } \\
\text { pressure } \\
\text { coefficient, } \\
\Psi_{0}\end{array}$ & $\begin{array}{c}\text { Pressure } \\
\text { coefficient, } \\
{ }_{0}\end{array}$ & $\begin{array}{c}\text { Discrepancy, } \\
\Delta, \\
\text { percent }\end{array}$ & & $\begin{array}{c}\text { Pressure } \\
\text { coefficient, } \\
\Phi_{0}\end{array}$ & $\begin{array}{c}\text { Discrepancy, } \\
\Delta, \\
\text { percent }\end{array}$ \\
\hline $\begin{array}{r}0.226 \\
.214 \\
.195 \\
.158 \\
.128 \\
.145\end{array}$ & $\begin{array}{r}0.186 \\
.176 \\
.176 \\
.164 \\
.153 \\
.145\end{array}$ & $\begin{array}{c}21.5 \\
22.0 \\
10.9 \\
2.7 \\
19.5 \\
0\end{array}$ & $\begin{array}{r}0.125 \\
.117 \\
.066 \\
.100 \\
.106 \\
.110\end{array}$ & $\begin{array}{r}0.108 \\
.108 \\
i^{085}\end{array}$ & $\begin{array}{r}15.3 \\
7.9 \\
28.8 \\
17.6 \\
24.7 \\
29.4\end{array}$ \\
\hline $\begin{array}{r}0.137 \\
.135 \\
.100 \\
.105 \\
.103 \\
.104 \\
.075\end{array}$ & $\begin{array}{r}0.089 \\
.089 \\
i^{108}\end{array}$ & $\begin{array}{r}54.3 \\
51 . .3 \\
8.4 \\
3.2 \\
5.2 \\
4.2 \\
44.5\end{array}$ & $\begin{array}{r}0.167 \\
.131 \\
.156 \\
.125 \\
.111 \\
.111\end{array}$ & $\begin{array}{l}0.184 \\
.108 \\
.175 \\
.075 \\
.075 \\
.125\end{array}$ & $\begin{array}{l}10.1 \\
21.7 \\
12.2 \\
63.8 \\
48 \\
12.7\end{array}$ \\
\hline
\end{tabular}


TABLE 3. - MODELING OF THE PRESSURE COEFFICIENT AT SHUTOFF $\left(\Psi_{0}\right)$ FOR TWO TRANSONIC COMPRESSORS

\begin{tabular}{|c|c|c|c|}
\hline Compressor & $\begin{array}{c}\text { Experimental } \\
\Psi_{0}\end{array}$ & \multicolumn{2}{|c|}{ Calculated $\Psi_{0}$} \\
\cline { 3 - 4 } &. & $\begin{array}{c}\text { W1 thout } \\
\text { correction }\end{array}$ & $\begin{array}{c}\text { Including } \\
\sqrt{M^{2}}-1\end{array}$ \\
\hline 26 & 0.145 & 0.164 & 0.128 \\
27 & .10 & .367 & .112 \\
\hline
\end{tabular}




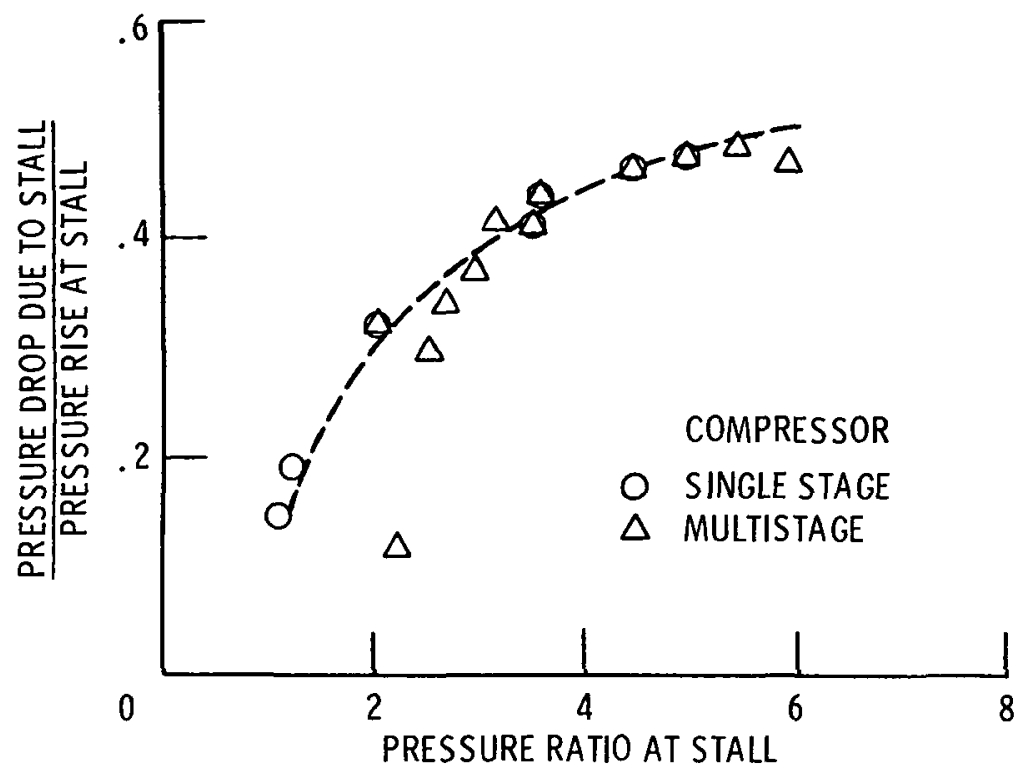

Figure 1. - Correlation of pressure drop at stall with compressor pressure ratio at stall.

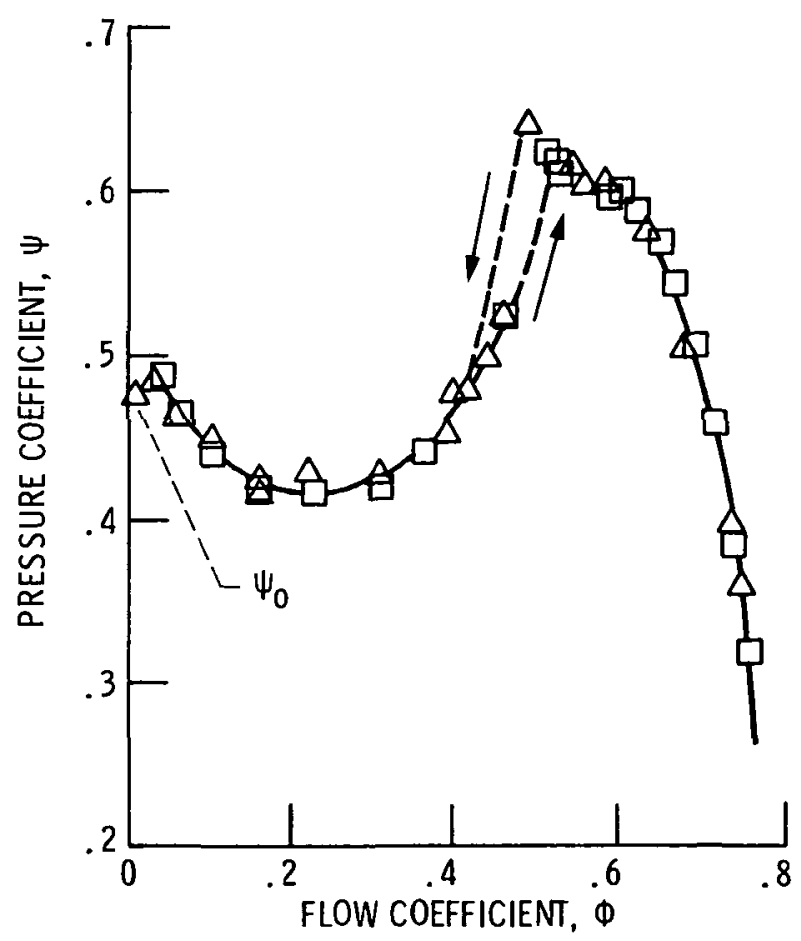

Figure 2. - Performance characteristic of a low-speed compressor. Compressor 4. 

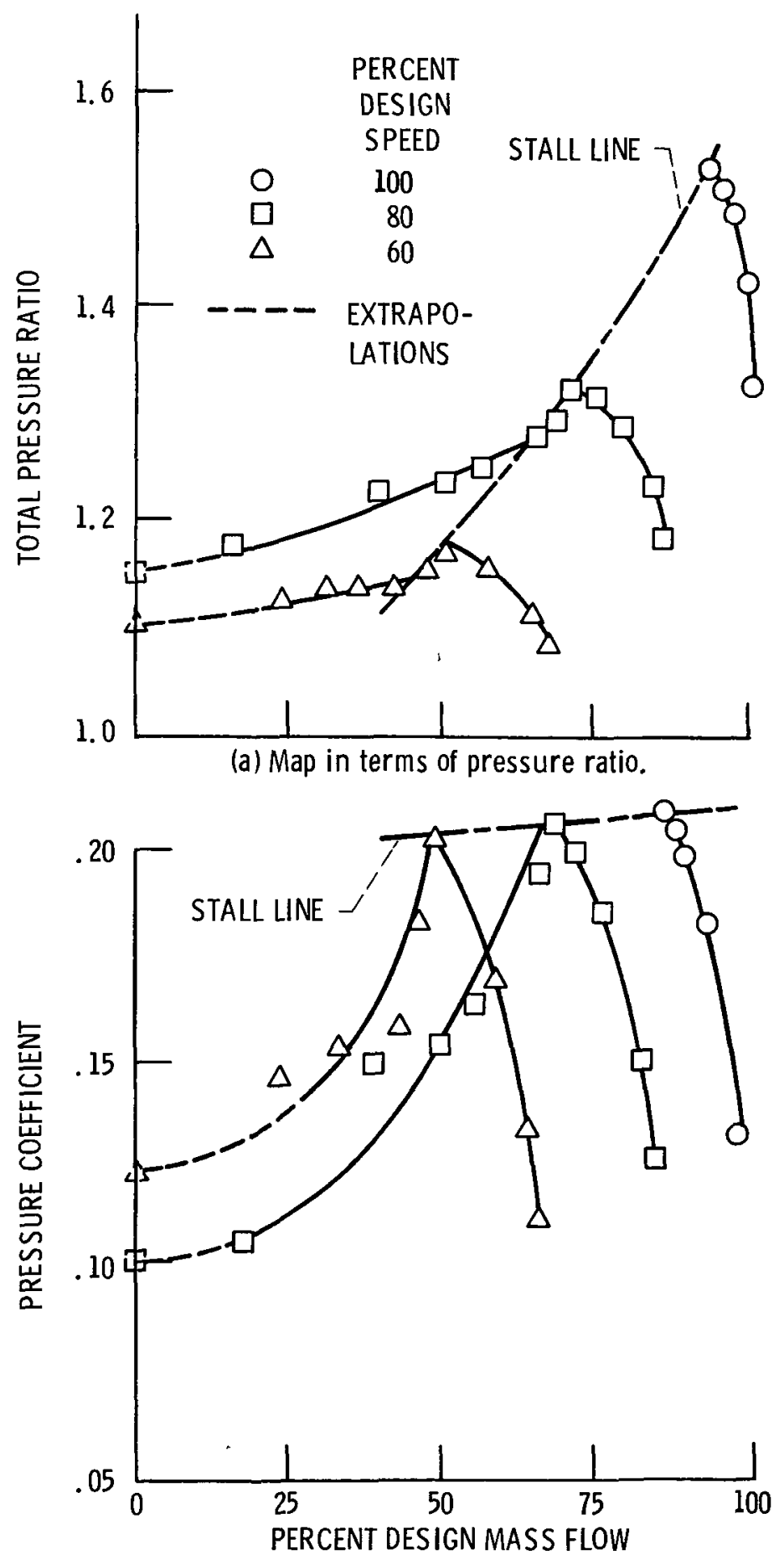

(b) Map in terms of pressure coefficient.

Figure 3. - Compressor 26 performance maps. 

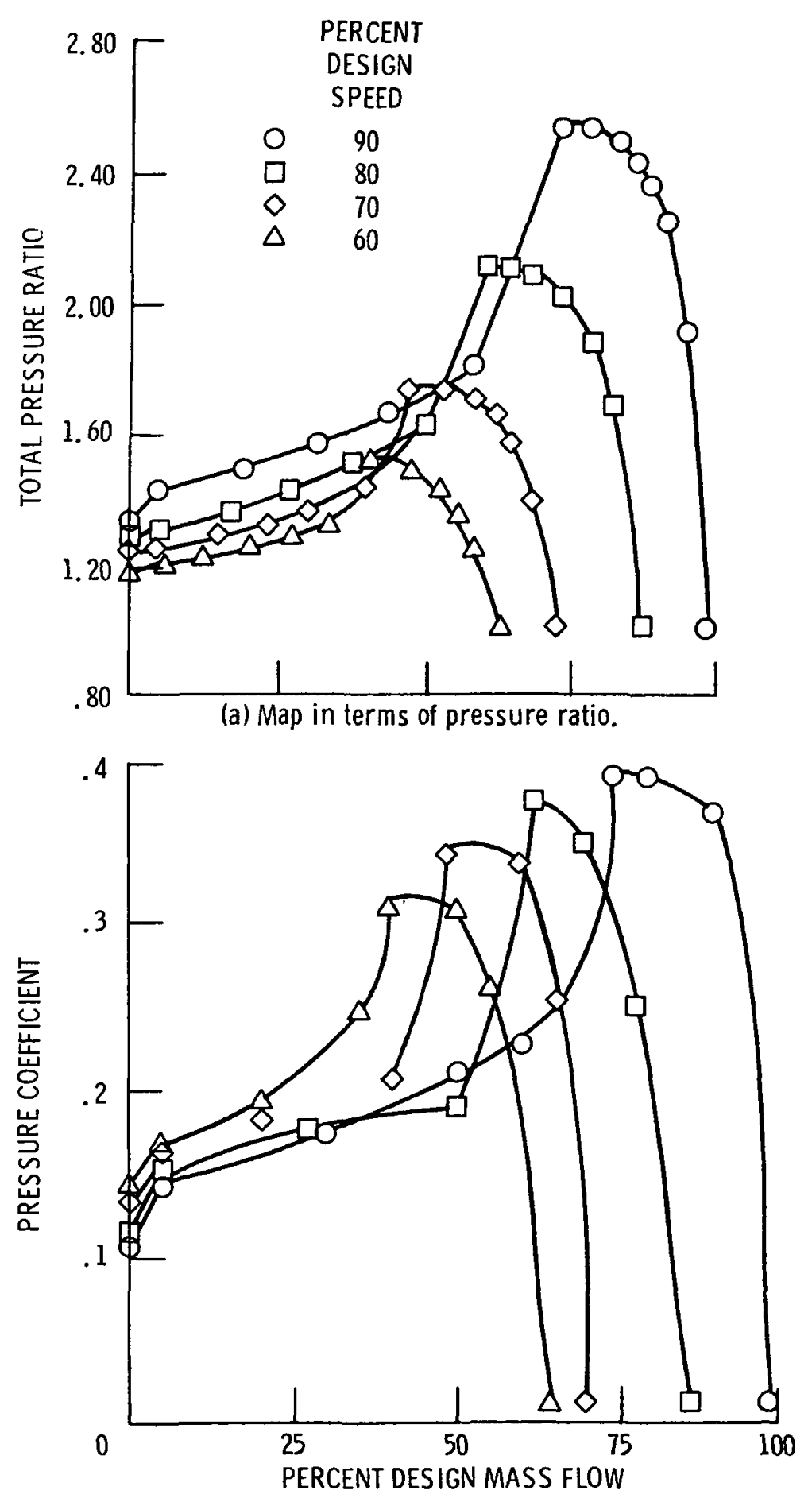

(b) Map in terms of pressure coefficient.

Figure 4. - Compressor 27 performance maps. 


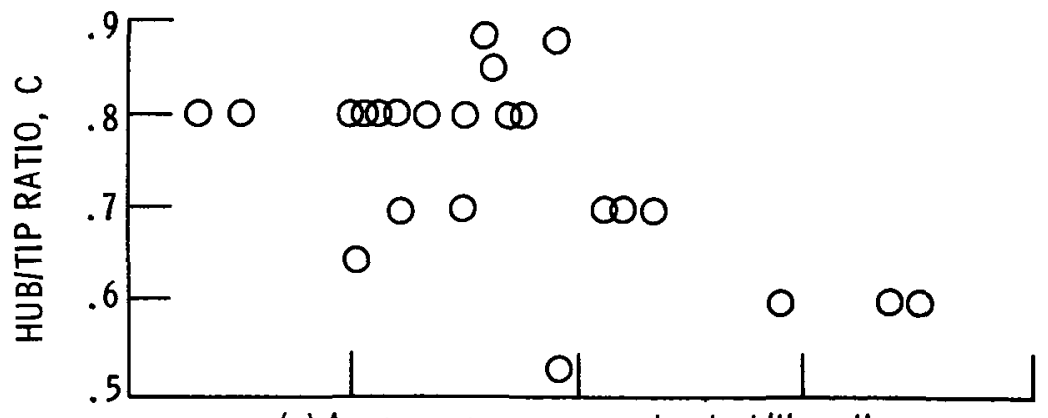

(a) Average compressor rotor hub/tip ratio.

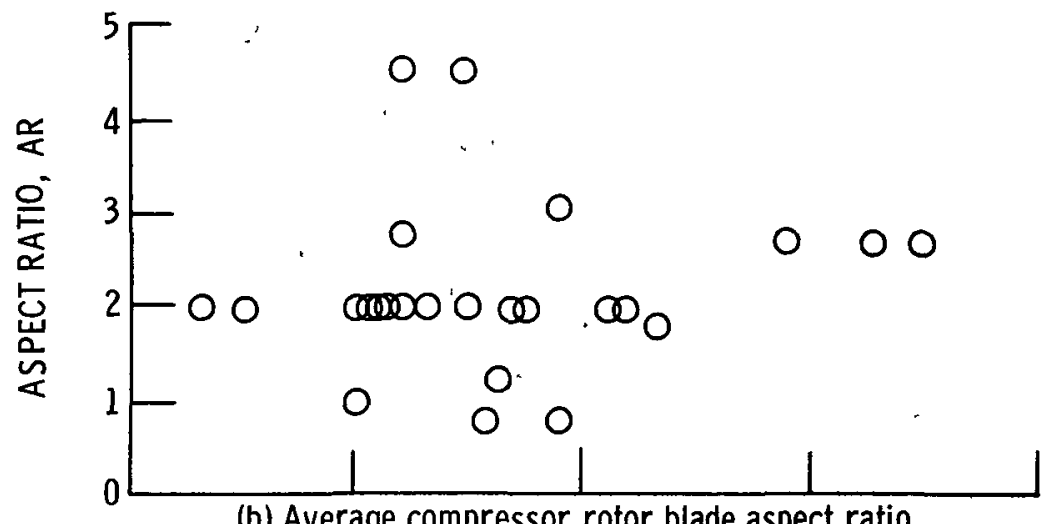

(b) Average compressor rotor blade aspect ratio.

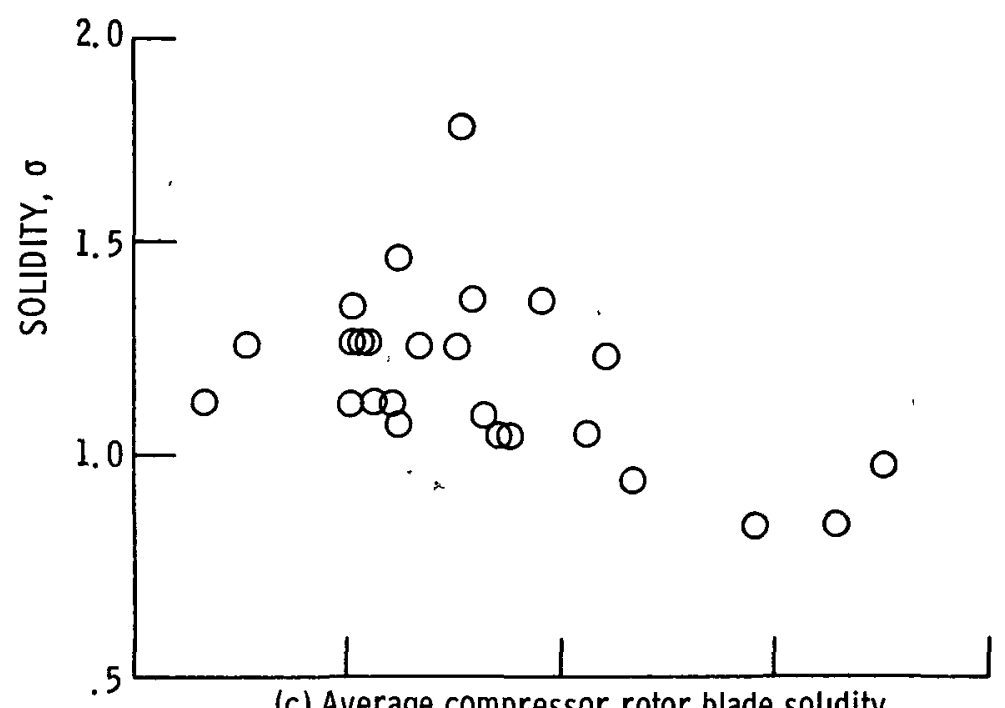

(c) Average compressor rotor blade solıdity.

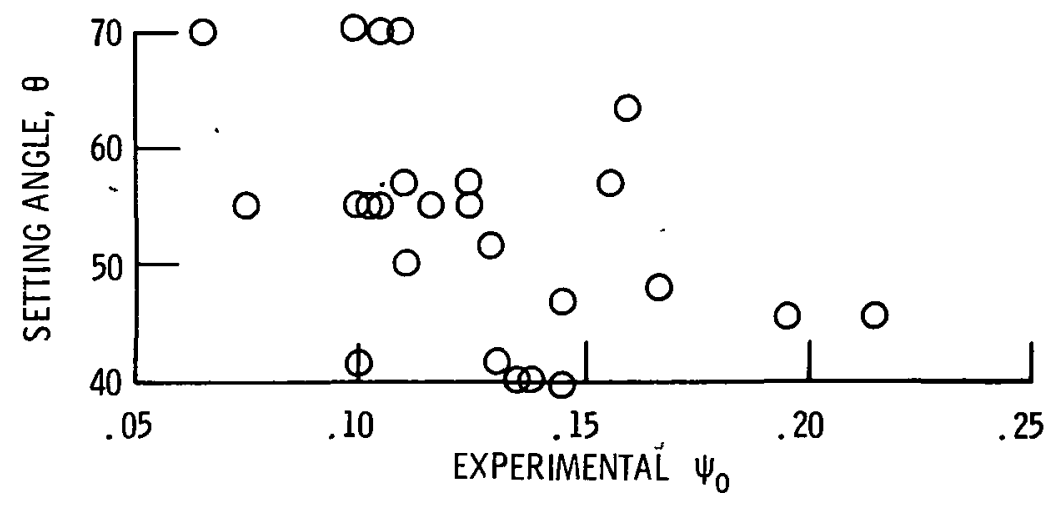

(d) Average compressor rotor blade setting angle.

Figure 5. - Compressor design parameters versus experimental pressure coefficient at zero flow. 


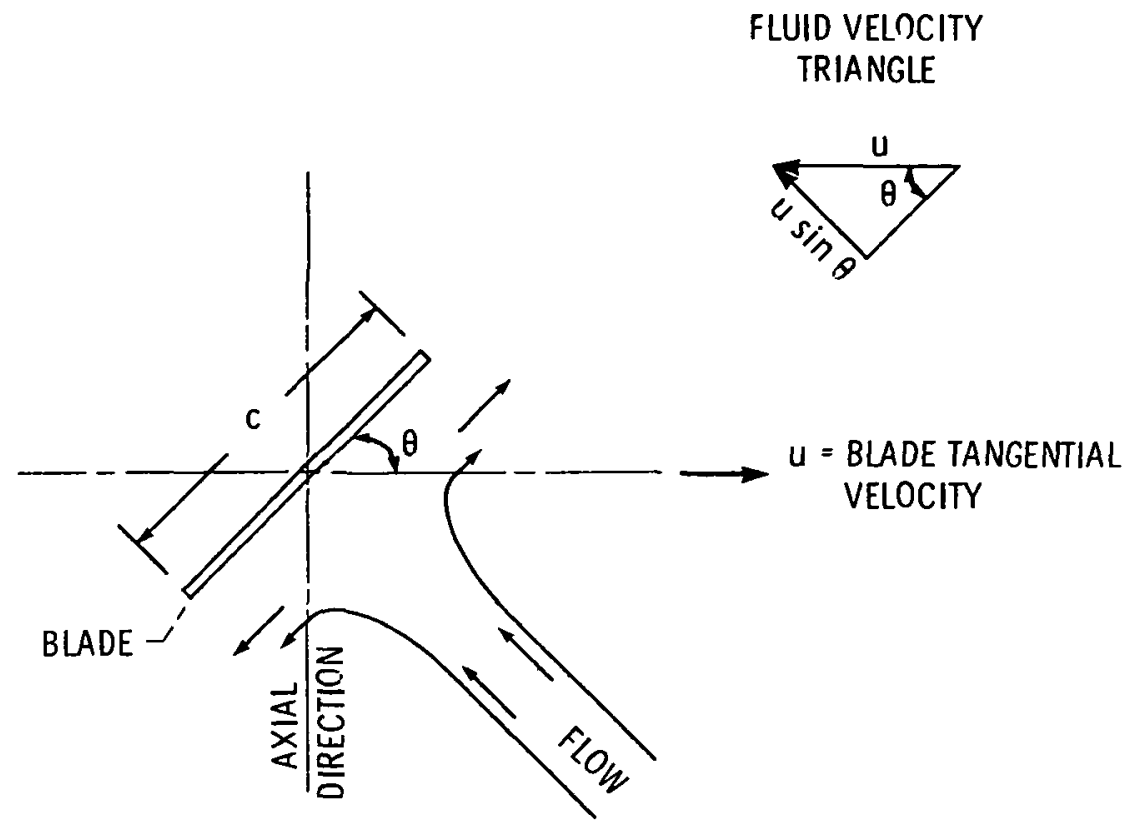

Figure 6. - Schematic of rotor blade operation in shutoff condition.

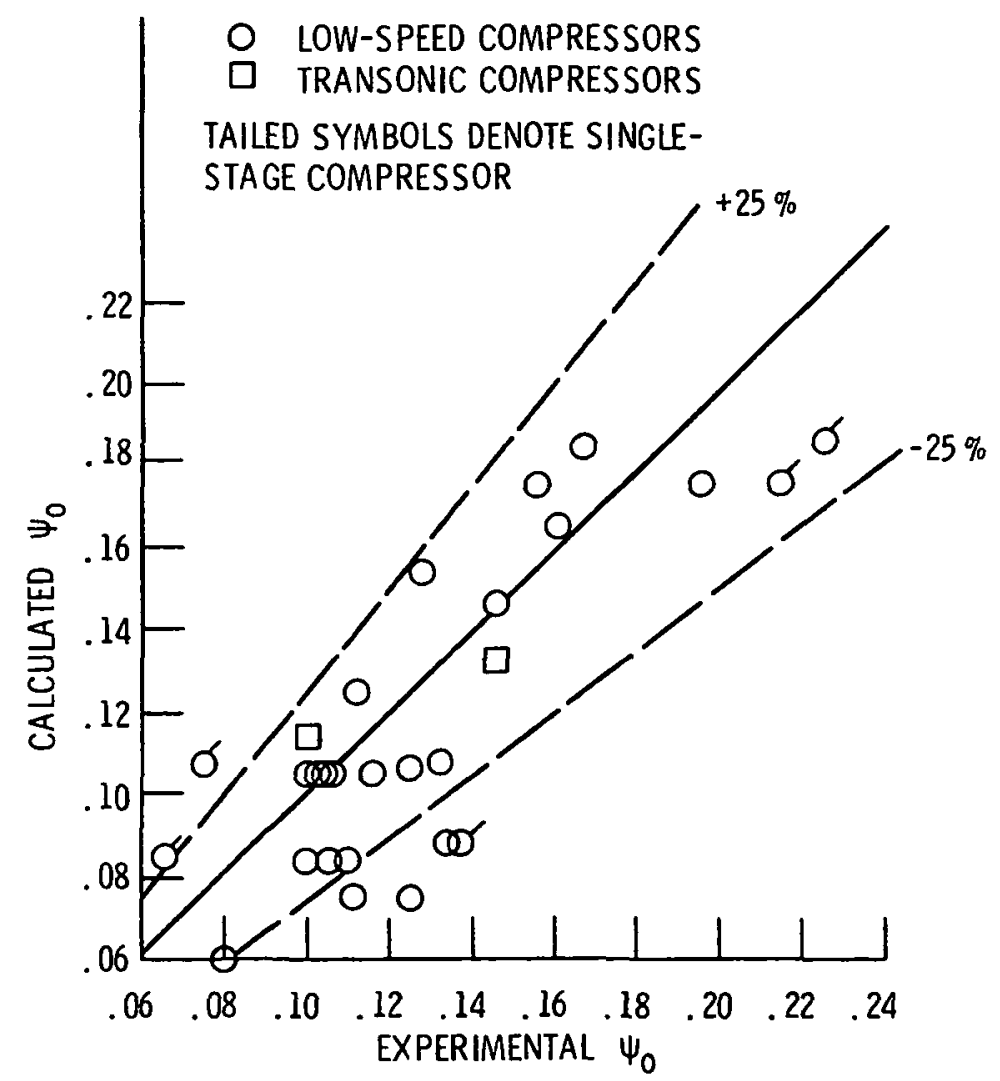

Figure 7. - Verification of validity of establıshed flow model. 


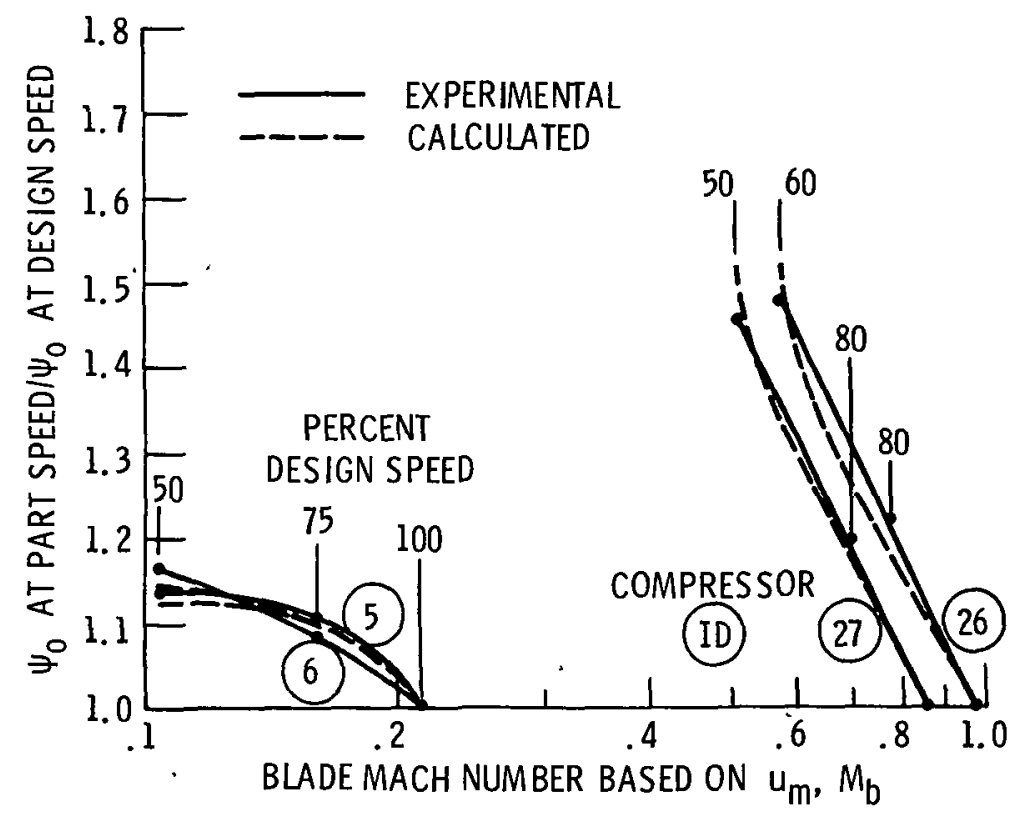

Figure 8. - Compressor part-speed operations at shutoff. 


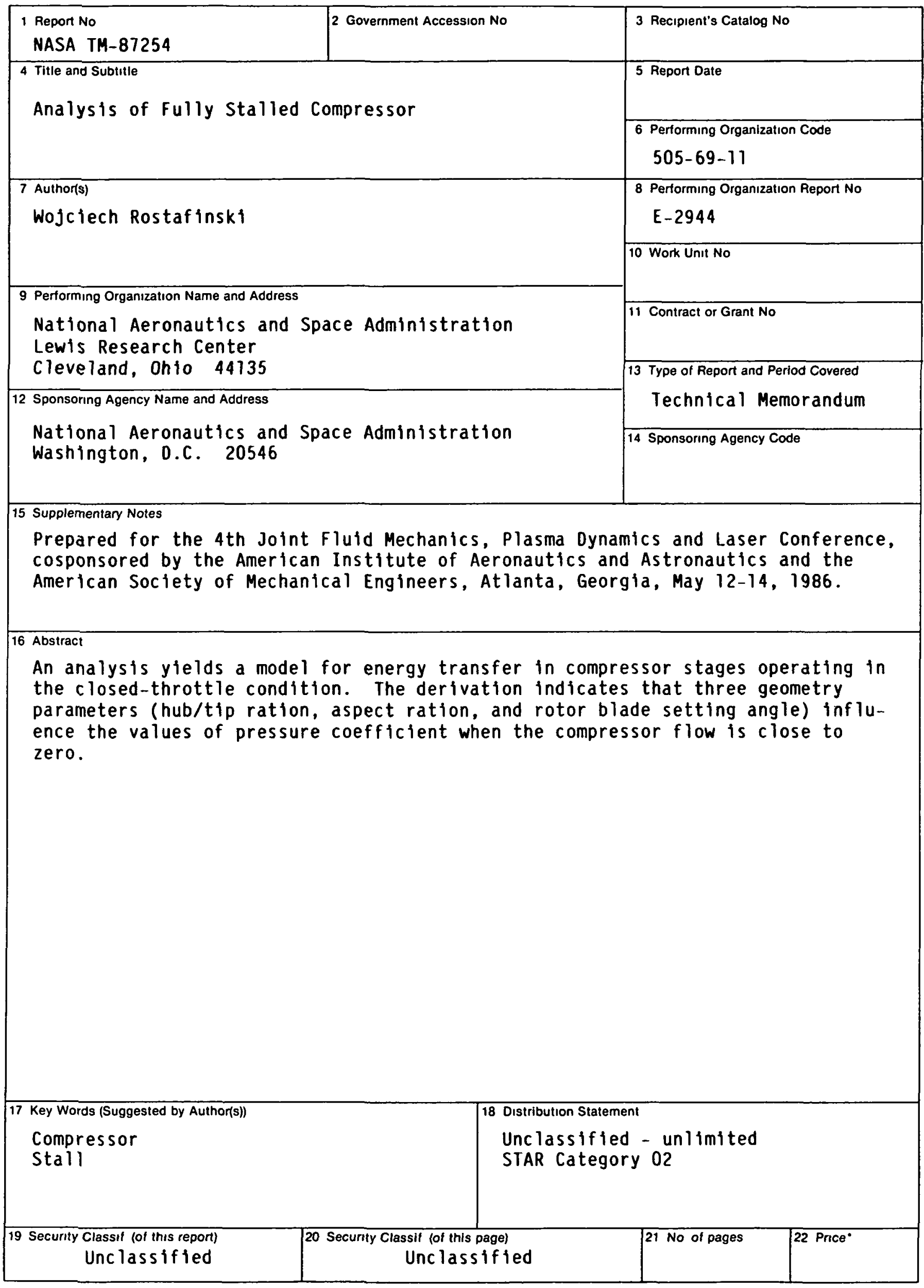

\footnotetext{
"For sale by the National Technical Information Service. Sprıngfield, Virgınıa 22161
} 
National Aeronautics and

Space Administration

Lewis Research Center

Cleveland. Ohı 44135

Ofictal Bustnoss

Penaly for Pitrato Use $\$ \mathbf{s 0 0}$
SECONO CLASS MAIL

ADDRESS CORRECTION REQUESTED

stage and Fees Pand

National Aeronautics and

Space Administration

NASA-451 